\title{
FUNCTIONS OF GUIDANCE COUNSELLORS AT ADULT EDUCATION CENTRES IN NIGERIA
}

\section{Dr. GALI SA'IDU}

\begin{abstract}
This paper examines functions of guidance counsellors at adult education centres in Nigeria.Equally, the paper reviews different definition of adult education, objectives of guidance and counselling units in adult education, scope of guidance and counselling center and problems affecting guidance and counselling center which prompted for the specific functions of counsellors at adult education center. Some of the specific functions of counsellors identified are provision of guidance on how to take decisions on important issues such as class to enroll into, how to adjust to class schedule, guide adult learners on how to search and manage jobs. In addition, the paper offers some recommendations among which include organizing orientation for new students, establishment of functional and fully equipped counseling centers, organizing career day activities arrangement for refferal of the clients' among others.
\end{abstract}

\section{Introduction}

One of most giant strides in the field of education at the end of 19 th century and begining of 20th century is the guidnace movement. Begining with the first systematic work of George Mervill in 1885 at the Califonia School of Mechanic in San Francisco, and the works of Frank Parsons (1908) on pprovision of vocational assistance to young people. The ideas of these two pioneers of guidance and counseling can be translated into three aspects of modern terminology, namely: the appraisal of the individual, the furnishing or occupational information and the provison of conseling (Salawu, 2008).

Guidance and counseling is a relatively new discipline but fast growing profession in Nigerian educational scene.The beginning of this discipline in Nigeria can be dated back to 1959 when a group of catholic sisters of St. Theresa's College, Oke Ado Ibadan felt the need to provide vocational guidnace and placement to their final year students (Makinde, 1984). The effort of the catholic sisters led to the formation of the nucleus of the then Ibadan careers council. Because of its national outlook, the council changed its name to Nigerian Careers Council and by the 11th day of December, 1976 the Counselling Association of Nigeria (CASSON) was inaugurated. One of the objectives of CASSON is to promote effective guidance and counselling in the interest of individuals and society (Okon, 1984). Guidance and counseling therefore, intends to cater for the individuals regardless of age.This includes adult learners attending adult education programme.

It is important to note that before the advent of modern guidance and counseling in the 1959 in this country, there was the existance of what is popularly reffered as "traditional counselling". Most of the societies have been held together by "traditional helpers"and they provide important services to the local people in their communities. They are known by various names depending on the locality which they operate. They are the 
“Babalowos"'Dibia", Älfa", Ëbra idiong", Äbia ibok", "Tsibbu”, "Bokayes", Prophets, fortune tellers and host of others"(Salawu, 2008; Okon, 1984).

Most of these people apart from been recognised by many Nigerians as those who could help others when they have personal concerns and problems which they said could solve easily, they equally provides some elements of guidance and counseling inform of giving advice and sharing wisdom. That is, they provided traditional counselling. In the modern sense' counselling goes beyond giving advice and showing wisdom. But the point of difference between modern and traditional counselling is that in the traditional counsellling, the counsellor is seen as having solution to the problem of the cclients while in the modern sense, the counsellor is not seen as having solution to the client's problem. But the best the counselor can do is to assist the client to have an insight to the possible cause of his/her problem and how to go about finding solutions to it (Salawu, 2008).

\section{Guidance and Counselling in Adult Education}

Adult Education as a discipline is as old as human race on earth (Yakusak, 2002). Edward (2007), define adult education as education that emphasis is placed on literacy education, education as a process and agent of liberation as tool for adjustment for self and national development, for cultural awarenes and integration for conscientization and group dynamism. Akinpelu, (1988) define Adult Education as:

...All and any deliberate and systematically planned educational activities that has the adult as its target, that is designed around the interest and self expressed concern of adult, the intention of which is to solve immediate problems are finally it is an acitivity that is usually part-time (pp. 17).

From Akinpelu definition one can view adult education as any organized, and systematic educational activity carried outside the framework of the formal system to provide specially selected learning experience to particular groups including adults, children and young people. In the words of Alkali, (2008) adult education programmes touch the lives of many people and when they are well planned adult education programmes have a high potential for contributing to individual and national development. But the achievement of this goal can be, facilitated with efforts of guidance and counseling.

However, another more encompassing definition of adult education which simplifies the remnant of guidance and counseling is the one given by Tugbiyele (1991) which stated that:

\footnotetext{
"By adult education we do not mean literacy alone. Adult education is more than literacy or remedial education to fill the gap. It is something people need and want as long as they are alive and regardless of the amount of their previous aducation. It must therefore be integret part of any modern country's education system" (pp.80).
}

The above definitions depicted the comprehensive nature of the adult education which seeks to meet the various needs and aspiration of adult education programme. However, Oduaran (1991) illustration on the form of adult education programme as shown below describes the need for guidance and counseling in adult education 
programme because of the various segments linked with adult education programmes with learners with different aspiration and a lot of educational, vocational and personal and social needs.

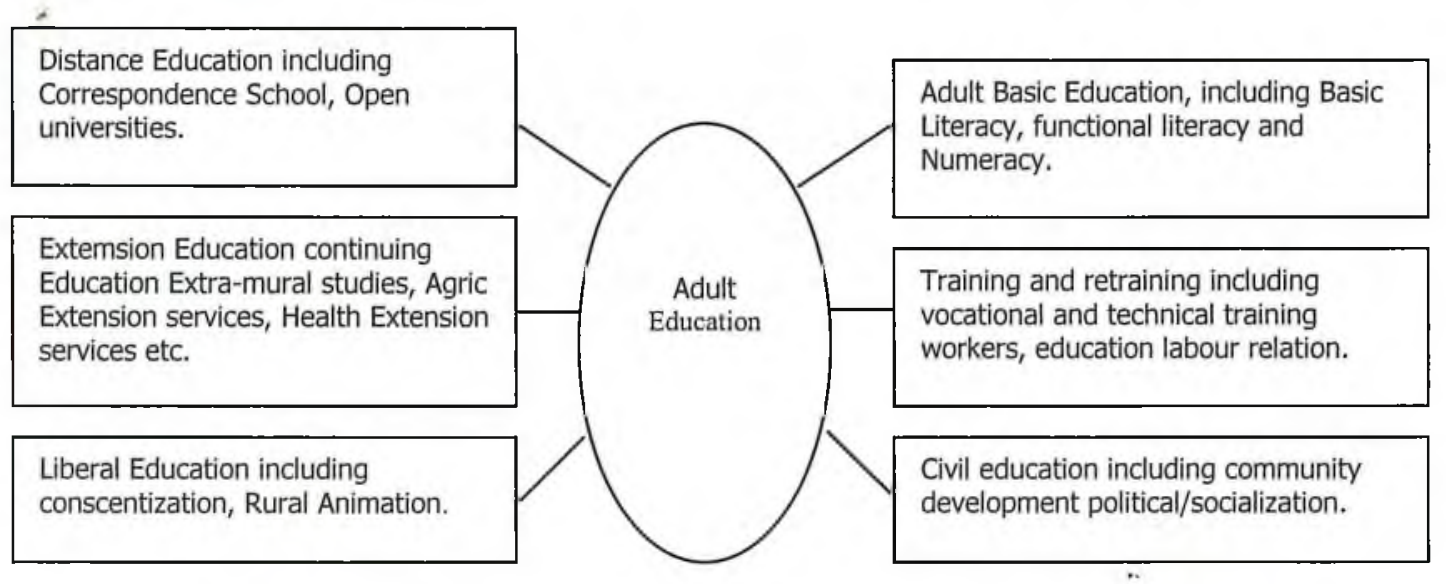

One major problem facing guidance and counselling in this country, is the lack of recognition and the realization of counselling as an integral part of the education and at all levels and forms of education. It is believed that adult learners need to be counsel or guided whether trained or untrained, graduate or non-graduate. Adult learners at different level enrolling into different forms of adult education need to be guided by trained and experienced "career master/mistress/ advisers".Similarly, adult education centers lacks train and experience counselors, they few ones has no adequate skills to assist adult learners. In most cases adult eduation centres there is no exisitng of counselling units and where it was found that there is no trained or professional guidnace-counsellors to manage them, and the worst part of the situation adult learners may not even know of their existence and no facilitators who perform the function para counsellors in most of the centres (Sa'idu, 2009). Consequently, most of the adult learnes will graduate without enjoying the benefit of having someone they will talk to, who will be non-judgemental in discussing their problems. In essence, they, adult learners complete their prgrammes with very little knowledge about themselves and how to cope with the realities and challenges they would face in their life. Arene and Durojaiye (1979) observed that the incorporation of guidance and counselling in the process of appraising and grooming the nation talents is necessary especially if education can be used as an instrument tool that of human and national development.

\section{Objectives of Guidance and Counseling Units in Adult Education Centres}

As one of the support services that can assist the attainment of the objectives for which adult education learners centres established, guidance and counseling unit in adult education centres is expected to:

a. Develop adult learners skills for better self-understanding;

b. Equip them with skills for self-improvement;

c. Provide information on family life education retirement adjustment skills ;

d. Highlight dangers inherent in various social vices (eg. Drug abuse, serst cults, arson, vandalism);

e. Help adult learners to develop better interpersonal skills;

f. Equip them with knowledge, attitude and skills for developing adult education adequate social skills and 
g. Assist them develop effective time management skills.

\section{Scope of Guidance and Counseling at Adult Education Centres}

A cursory look at the objectives of guidance and counselling units stated above, one can say with some degree of certainty that problems that could face adult learners in adult education centres can be categorised into: educational, vocational personal-social and psychological. In order to accomplish these objectives, the effort the guidance counsellor should address the four areas. It can be said here that making guidance are counselling operational and available to learners at adult education centres, there is need to inculcate into them with a greater knowledge of educational, vocational and personal-social opportunities so that they make better informed choices, decisions and cope with challenges in this and increasingly complex society.

a) Educational Guidance Counselling: Attendees of adult education programmes are often faced with many eduational problems. These problems include of absence of information related to eduation especially inconsideration of the various reasons that motivates them to enrol into adult eduation programmes which are conflicting. But the most of these problems include confusion of class to enroll (i.e. basic literacy, post literacy, remedial class etc), poor study habit due to age, responsibilities; poor note taking, difficulty in taking examinations and tests in cases of remedial classes, and above all lacking someone to whom they can freely confide their concerns (i.e. guidance counsellor).

b) Vocational Guidance-Counselling: Participants attending adult education programmes are of different ages and a great number of them experience problems in their vocational development. This include lack of knowledge of their own aptitudes and interest, lack of realism, indecision, inflexibility an unwillingness to change, as well as lack of occupational infromation, problem solving skills (Weinrach, 1979).

However, in a constantly changing world, attendees of adult education programme lack contents that promotes the use and access to current occupational information, unable to clarify their own values, feelings and attitudes and relate them to educational and vocational standards (Olayinka, 1988). This is shown on their inablity to cope with the challenges emerged as a result of technological advancement and their unrealistic choices of career and vocations thus, they left ungided adult attending the adult education programmes are more prone to choose occupation and career without directly relating them to their interest, aptitude, ability and talen, and without considering other conditions relevant to the job. (Olayinka, 1988).

c) Personal-Social Guidance Counselling: In a society such ours where ethnic and tribal hatred is experienced, are a society which growing into a complex and fast changing some participants or adult education programme they often do not understand what is happening or what to do about it and coupled with other personal and social problems emenating from the society in general. They attendees' of adult education programme may be affected with problems such as anxiety, stress, poor self image, difficulty in asserting themselves, drug and alcohol abuse, alcohol and tobacco problem, teenage pregnancy, sexually 
transmitted infectious (STIs), suicide, difficulty in making decisions and solving problems.

From foregoing one can appreciate that the scope of adult education is wide and contain issues that need expert handling like counsellors because the scope of adult education geared towards ameliorating educational, vocational and personalsocial problems of adult learners.

\section{Specific Functions of Guidance Counsellors at Adult Education Centre in Nigeria}

A critical look at the previous discussion especially on the objective of guidance and counseling unit at adult education Centres'and the scope which guidance and counseling intends to address gudiance counsellors can perform the following specific functions which include:

a) Guidance counsellors should through the use of educational gudiance can provide services to the attendees of adult education centres to take decision about important aspect related to their education especially the class to enroll, streamline their reasons for enrolment into adult education centres, adjust to the class schedule, content taught, improve their study habit and note taking ability, to manage examination phobia and anxiety. To achieve this, guidance counsellors are expected to mount educationally related guidance services such as academic counselling, orientation programmes, study habit programmes, adult education centre days, conferences and other programmes that help the attendees of adult education programme. However, guidance programme should assist adult learners on how to utilize their time judiciously, how to map out approapriate educational goals, understand themselves and to develop potentials. Educational guidance therefore, can be seen as the process of rendering services to attendees of adult education programme who need assistance in taking decision about important aspects of the adult education prgramme. This could promote their knowledge of educational opportunities, or what (Salawu, 2008) described as "an institution that promote and provide preventive, remedial and developmental education".

b) As service provider guidance counsellors can offer the helping service to the attenddes of adult education programme who expeirences problems in vocational development especially, those who experience difficulty in searching jobs, because most of them lack knowledge of their own aptitudes and interest, some of them especially, the young ones are not realistic in their choice, they are indecisive, inflexible and unwilling to accept and adopt a charge. To achieve this the guidance counsellors can employ career education. Career education provides the attendees of adult education with ability to acquire skills, aptitude and information necessary for them to successfully enter the labour market, manage the challenges of job searching, and equip them with means of marketing their products.

Similarly, career education should not limit to vocational choice to self knowledge but it should assist adult learners on how match their personal attributes with their job the enrolled into or intending to enrolled into. As noted by Walton (1966) citéd in (Salawu, 2004) that career education could be regarded as the process of helping a person match his personal attributes and his background with suitable jobs and employment opportunities. Thus, it suppose to be a multi dimensional 
field which provides students or individual with job motivation, professional and academic education skills through the life span of the individual (Egbule, 2006).

However, guidance counsellors are expected to provide organised systematic information service related to various types of occupations which serve the informational needs of adult learners. The occupational information must be usable and valid as well as clearly states the available job positions, requirement and challenges. However, the information should further states the duties, requirements for entry conditions of work, rewards offered, advancement patterns existing and predicted supply of and demand for workers and sources for further information (Makinde, 1984). To achieve this guidance counsellors can apart from career education, they can make use of career conferences which Ipaye (1983) refers it as career convention, other coined as career day, career week, career forum or career symposium (Egbule, 2006).During which adult learners will adequately be inform about the various outlet for white collar jobs and other nonwhite collar jobs outlets, the requirement and challenges as well as prospect of the various jobs.

Similarly, guidance counsellors can make use of field trips or excursions where the guidnce counsellors provide vocational information or service to attenders of adult education programme by taking them out on field work to various places of work. But it is important to consider considereing the tight schedule and responsibilities of the attenders before organizing the trip. Thus, the schedule for the trip most is timely so that it will not clash in with their schedule of duties and responsibilities of adult learners. Individual vocational counselling in another strategic that can be used by guidance counsellor to assist the attendees'of adult education programme to have deep insight into the vocations because it assist them to identified, analysed and evaluate their vocational problems.

c) Guidance counsellors' are not only prepare to help attenders of adult education programme about their educational and occupational opportunities but most also assist them to understant themselves and other people for the purpose of reducing the level of ethno-religious conflict and other personal and social problems.

Guidance counsellors' need to provide personal-social information which assist adult learners to develop self-understanding and how an individual can get along with other people, assist them to develop healthy personalities. To achieve this counsellors' can use individual and group counselling to inculcate social skills, assertiveness skills, plan for leisure time, information on stress management, skills for managing learning difficulty such examination phobia, test anxiety etc.

\section{Conclusion}

Counselling as a "tailor made", the functions of guidance counsellors in adult education centers can assist in the improve on the quality of the product of those attending adult education programmes in the various centers in Nigeria particularly if the services of trained, experience and professional person are incorporated in the programmes of adult education centers. This is paramount in consideration of the vast and wide scope of the programmes run in those centers and the heterogonous nature of the learners because they are drawn from different ethnic, religious, social and economic backgrounds with 
different purpose, reason, mission and vision for enrolling into the adult education centre necessitate the services of guidance counsellors.

\section{Reçommendations}

Based on the above conclusion, the following recommendations were made:

a) Guidance counsellor should organize orientation for new adult learners to address some salient issues to their academic and non-academic matters.

b) Distribution of students hand book at the point of registration.

c) Organize career activities, or visit professional at work, hold talks on issues of relevant to their physical health, economic and social life.

d) Expose learners to behavior modification techniques for the purpose of promoting their productivity in life and reduce life threaten diseases etc.

e) Establishment of functional and fully equipped counseling center. 


\section{References}

Alkali, M. (2003). Professionalism in Adult Education. The surest way for effective administration of adult education in Nigeria. Sokoto Educational Review, 10 (1): 200210 .

Arene, V. N. \& Durojaiye, M. O. A. (1979). Nigerian Guidance and Counseling programme in Nigeria in V. J. Dropelaleds, Guidance and Counseling around the world. Washington DC: Uni. Press of America.

Akinpelu, J. A. (1988). Introduction to Philosophy of Adult Education Ibadan Dept. Of Adult Education University of Ibadan, External Studies Serie.

Edward, A. E. (2007). Planning Strategies of adult education programme development for the attainment of Millennium Developent Goals adult Education in Nigeria.Lagos: II NCAE:

Egbuls, J. F. (2006). Guidance Services. In Okobiah, O.C. Okorodudu, R.I. (eds) Issues, concepts, theories and Techniques of Guidance and Counseling. Edo: Ethiope Publishing corporation.

Oduaran, A. B. (1991). Proffessionalism, Training, needs and Institutional capacity in A.Fajonyomi \& O. Biao (eds) Policy issues in Adult and Community Education. Lagos: JCP Ikosi ketu Nigeria.

Okon, S. E. (1984). Gudiance for 6-3-3-4 system of Education. Zaria: Institution of Education, ABU.

Olayinka, M. B. (1988). Counselling Needs of the Adult in Oyedeji, L, (edit). Coping with learning in Adult years. Lagos: Joja Educational Research and Publication Limited.

Salawu, A. A. (2008). The importance of Guidance and Counseling unit in Tertiary Institutions, Sokoto Educational Review. 10 (1): 193-199.

Saidu, G. (2009). A survey of guidance services in adult education centers' in Kano and Jigawa States, Nigeria. A paper presented at workshop organized by Mazhab international consultant.

Weinrach, S. G. (1979). Career Counselling. New York: Mccraw-Hill Book Company.

Yakuseek S. N. (2002). Revatalizing Literacy in Northern programmes in the Northern Nigeria. A paper presented at Pre-submit of adult education programmes in the Northern states Nigeria Arewa House, Kaduna. 